\title{
POLITIK HUKUM DALAM PENERAPAN UNDANG-UNDANG ITE UNTUK MENGHADAPI DAMPAK REVOLUSI INDUSTRI 4.0
}

\author{
Alwi Al Hadad \\ Ilmu Hukum, Pascasarjana UIN Sunan Gunung Djati Bandung, Indonesia \\ Email : :alwi.28maret@gmail.com
}

\begin{abstract}
The purpose of this article is to explain the role of law in offsetting the acceleration of the cycle of human civilization in order to create an orderly life in a society. The method used to discuss the focus of this research uses a normative juridical approach and analysis of the effect of the acceleration of the civilization cycle in the process of reform and law enforcement. Using a qualitative approach and literature study as data collection, the authors found that the abandonment of laws from civilization causes a crisis in law enforcement. In essence the industrial revolution 4.0 shifts the human mindset in life and in society. This era will facilitate various community activities in various fields, especially in the field of technology. However, this is not the only effect it has on various sectors, namely the political, economic, social and legal spheres. Apart from the positives, this period had several negative effects, including the increase in unemployment due to human labor being replaced by machine power, natural damage caused by industrial exploitation, as well as many unclear news about the effect of easy access to information dissemination. The implication of this finding is that it recommends government action to reform regulations to tackle the negative impact of the 4.0 industrial revolution.
\end{abstract}

Keywords: Industrial Revolution 4.0, Legal Reform, Political Law,

\begin{abstract}
ABSTRAK
Tujuan artikel ini untuk menjelaskan peran hukum dalam mengimbangi percepatan siklus peradaban manusia agar terciptanya kehidupan yang tertib dalam suatu masyarakat. Penggunaan metode untuk membahas fokus penelitian ini menggunakan pendekatan yuridis normatif serta analisis terhadap pengaruh percepatan siklus peradaban dalam proses pembaharuan dan penegakkan hukum. Menggunakan pendekatan kualitative serta studi pustaka sebagai pengumpulan data, penulis menemukan bahwa tertinggalnya hukum dari peradaban menjadikan krisis dalam penegakkan hukum. Pada hakikatnya revolusi industri 4.0 menjadikan bergesernya pola pikir manusia dalam kehidupan dan dalam bermasyarakat. Era ini akan mempermudah berbagai aktifitas masyarakat di berbagai bidang, terutama dalam bidang teknologi. Akan tetapi tidak hanya itu efek yang ditimbulkan berpengaruh ke berbagai sektor, yaitu ranah politik, ekonomi, sosial, dan juga hukum. Selain dari hal positif masa tersebut menyimpan beberapa efek negatif, diantaranya penambahan angka pengangguran akibat tenaga manusia yang digantikan oleh tenaga mesin, kerusakan alam disebabkan eksploitasi industri, serta banyak berita yang belum jelas kebenarannya efek mudahnya akses penyebaran informasi. Implikasi dari hasil temuan ini merekomendasikan perlu adanya tindakan pemerintah untuk memperbaharui aturan dalam menanggulangi dampak negatif dari revolusi industri 4.0 tersebut.
\end{abstract}

Kata kunci: Politik Hukum, Pembaharuan Hukum, Revolusi Industri 4.0

\section{PENDAHULUAN}

Berbagai pembaharuan dalam ranah teknologi sering dikaitkan dengan munculnya Era revolusi industri 4.0, bermacam fasilitas disuguhkan dalam mengurangi beban kerja manusia, diantaranya dengan

* Copyright (c) 2020 Alwi Al Hadad

This work is licensed under a Creative Commons Attribution-ShareAlike 4.0 International License. 
menciptakan robot buatan yang didesign menyerupai manusia baik dalam hal fisik maupun kecerdasannya, adanya pembuatan rekayasa genetik sampai pada tingkat otomatisasi yang berdampak pada pergeseran dalam ranah sosial. Berbagai perubahan yang terjadi akibat adanya revolusi industri ini berdampak pada segi kehidupan manusia. Kondisi ini terjadi baik dalam ranah publik maupun privat yang sasarannya mendominasi pada kaum milenial. Perubahan yang terjadi berdampak besar dalam kehidupan bermasyarakat diberbagai kalangan yang akibatnya mengarah pada terjadinya revolusi sosial. William P. mengemukakan dalam perubahannya teknologi berperan menjadikan komunikasi menuju tingkat lebih tinggi terhadap perubahan sosial (in its change technology plays a role in making communication towards a higher level of social change) (Astuti, 2019).

Robert H. Lauer berpendapat tingkat kehidupan sosial berkembang sangat pesat beriringan dengan perubahan zaman sehingga berimbas pada pergeseran norma-norma yang ada dalam masyarakat. Perubahan yang dominan diantaranya dalam ranah norma sosial, interaksi sosial, nilai sosial, organisasi sosial, pola prilaku, lapisan masyarakat, organisasi sosial, hingga pada susunan wewenang dan kekuasaan (Saebani, 2016).

Dengan adanya hal tersebut, maka harus adanya upaya dalam proses pembangunan yang berjalan secara teratur serta berkelanjutan dari berbagai sektor. Soerjono S. berpendapat dalam pembangunan, yaitu proses perubahan teratur serta terencana di antaranya mencakup bidang ekonomi, politik, demografi, hukum, psikologi, teknologi, maupun bidang intelektual (Soekanto, 1980).

Menurut Soekanto (1980), munculnya berbagai teknologi mengakibatkan adanya pergeseran di dalam masyarakat. Hal tersebut bisa dari segi nilai-nilai sosial, pola-pola perilakuan, kaidah-kaidah sosial, organisasi, serta susunan lembaga kemasyarakatan. Peran penting dipegang oleh perubahan teknologi dari berbagai sektor. Ketergantungan manusia terhadap teknologi dapat merubah kultur dan budaya yang ada dalam masyarakat, akan tetapi tetapi adanya anggapan bahwa teknologi modern dapat membawa kepentingan dan keuntungan yang besar bagi negara-negara di dunia, sehingga secara tidak langsung adanya pergeseran kebiasaan dalam masyarakat (Raharjo, 2002).

Di era teknologi informasi pembentukan peraturan perundang-undangan perlu dilihat dari berbagai aspek. Sebagai contoh pada ranah pemanfaatan dan pengembangan jurudiksi dan konflik hukum, internet dan rule of law, legalitas hukum mengenai dokumen dan tanda tangan elektronik, caracara penyelesaian sengketa domain danpengaturan conten, serta privasi dan perlindungan konsumen, lebih lanjut mengenai cybercrime (Sujamawardi, 2018).

Adanya pelbagai perubahan dalam ranah ekonomi, sosial, budaya, serta politik disebabkan adanya percepatan perkembangan sains dan teknologi (Mukhadis, 2013). Perkembangan teknologi informasi merupakan salah satu ilmu pengetahuan yang paling cepat kemajuannya dibanding ilmu-ilmu lainnya. Secara tidak sadar dapat kita rasakan efeknya sampai saat ini, dengan berbagai kemudahan fasilitas yang disuguhkan bahkan dengan adanya internet bisa menjadi pekerjaan bagi sebagian orang yang sering kita tengal dengen (youtuber). Akan tetapi privatisasi akang mulai berkurang dengan adanya hal tersebut karena aturan-aturan yang ada di dalamnya berbeda dengan aturan dalam stasiun televisi. Terkadang orang bisa bebas dalam menyampaikan aspirasinya, tentu saja dalam hal ini pemerintah harus bisa mengatur lebih jauh dan bisa masuk ke ranah itu. Agar pelanggaran-pelanggaran yang ditimbulkan tidak terjadi.

Beberbagai kalangan menjadikan fasilitas ini sebagai bahan diskusi publik dalam membahas berbagai fenomana yang ada, tentu saja ada yang bersifat mengkritik dan juga saran terhadap tindakan pemerintahan terkait fenomena tersebut. Eksistensi internet sangat berpengaruh terhadap budaya masyarakat saat ini. Interaksi sosial dapat dirubah dengan praktis tanpa bertemu secara langsung 
sehingga dalam keadaan tertentu hal ini dapat dijadikan solusi dalam menghadapi masalah yang timbul dalam masyarakat.

Indonesia merupakan negara dengan masyarakat yang konsumtif terhadap berbagai hal terutama dalam penggunaan internet dan media sosial. Berbagai kalangan turut andil di dalamnya dimulai dari usia muda hingga lanjut usia sehingga menjadikan Indonesia sebagai negara yang menjadi penyumbang pengguna internet terbesar khususnya di tataran Asia Tenggara. Oleh karena itu untuk mengantisipasi semakin maraknya penggunaan internet dan semkin marak pula tindak kriminal yang semakin muuncul ke permukaan, maka pemerintah perlu membentuk suatu peraturan perundang-undangan sebagai solusi dalam mengantisipasi dan menindaklanjuti pelanggaran hukum yang ada di dalamnya.

Dengan adanya kemunculan internet ini pemerintah dapat mengambil sikap melaui ambisinya, yaitu untuk menegakkan kedaulatan dengan seluas-luasnya. Akan tetapi pondasi yang kokoh sangat diperlukan oleh negara, karena tidak dapat dipungkiri dengan adanya kebebasan yang ditawarkan oleh internet maka dampak yang dihasilkan juga tidak selamanya positif melaikan ada juga dampak negatifnya.

Dalam beberapa momentum internet dapat dijadikan senjata ampuh dalam menggapai keinginan beberapa kalangan terkhusus dalam kegiatan kenegaraan, akan tetapi internet ini cenderung lebih sering digunakan pada momen-momen penting, yaitu pada saat pemilihan umum. Karena ada beberapa kemudahan yang ditawarkan dalam proses berjalannya pemilu tersebut. Dimulai dari sosialisasi, proses kampanye hingga pada proses hitung cepat yang dilaksanakan sebagai gambaran umum menuju hasil dari proses pemilu. Selain itu Indonesia saat ini sedang menjalani maraknya industri di bidang ekonomi dengan adanya trand online shop, ojek online, go food, e-money dan lain sebagainya yang berbasis online dan tidak dapat dipungkiri dapat merubah tatanan kehidupan masyarakat dari berbagai aspek kehidupan.

Beberapa penelitian terdahulu (Idayanti, Hartati, \& Haryadi, 2019; Palinggi \& Allolinggi, 2019; Palinggi, Palelleng, \& Allolinggi, 2020) menyatakan bahwa peningkatan kesadaran masyarakat Indonesia dalam menghadapi era Society 5.0 dan tetap waspada terhadap bentuk-bentuk perubahan kejahatan cyber seperti penipuan dan pencurian data maupun informasi penting yang dimiliki. Pada penellitian ini penulis mengambil fenomena berbeda baik dari metode maupun masalah yang diambil dan lebih banyak focus kepada perundang-undangan.

Dengan adanya peraturan perundang-undangan terhadap penggunaan internet dan media sosial diharapkan mampu dalam menyelesaikan persoalan-persoalan yang ada. Terutama menuju proses pembangunan etis bagi para pengguna media supaya dalam proses penggunaannya dapat dengan bijak dilakukan sesuai dengan norma-norma, budaya, serta peraturan perundang-undangan yang ada.

\section{METODOLOGI PENELITIAN}

Metodologi untuk membahas fokus penelitian ini, yaitu dengan menggunakan pendekatan yuridis normatif serta analisis terhadap pengaruh percepatan siklus peradaban dalam proses pembaharuan dan penegakkan hukum. Dalam proses penelitian penulis lebih mengarah terhadap pengaturan perundangundangan serta penegakkan dan pembaharuan hukum terhadap pelanggaran yang terjadi berdasarkan asas keadilan dan kepastian hukum.

Dalam proses penelitian penulis menganalisis fenomena sosial yang ada dalam masyarakat serta memperhatiakan pengaturan kebijakan terhadap pelanggaran yang dikeluarkan oleh pemerintah yang berwenang terkait hal itu. Sehingga kesimpulan dapat diambil dari proses tersebut. 


\section{HASIL DAN PEMBAHASAN}

\section{Peran Politik Hukum dalam Tujuan dan Pembaharuan Hukum}

Menurut Satjipto Rahardjo, politik hukum mempunyai peran sebagai aktivitas pemilihan sarana dalam mencapai suatu tujuan dalam suatu tatanan hukum maupun sosial tertentu di dalam suatu masyarakat. untuk mengkaji pembahasan mengenai materi tersebut terdapat beberapa pertanyaan mendasar yang sering muncul, diantaranya yaitu: Pertama, mengenai tujuan yang nantinya akan digapai dengan menggunakan sistem hukum yang ada; Kedua, mengenai penggunaan cara yang dirasa efektif dalam mencapai tujuan tersebut; Ketiga, mengenai cara dalam proses perubahan hukum serta waktu yang tetap dalam proses perubahan hukum tersebut; Ke empat, mengenai perumusan pola yang dapat membantu dalam menentukan suatu tujuan serta penentuan cara-cara untuk mengapai hasil dari tujuan tersebut dengan baik (Rahardjo, 2006).

Politik hukum merupakan gambaran suatu kehendak ataupun keinginan negara terhadap hukum. Hal tersebut dapat berupa kebijakan pemerintah mengenai hukum yang diterapkan, dipertahankan, diganti, direvisi dan di hilangkan. Oleh sebab itu, dengan menggunakan politik hukum negara membentuk suatu rencana dan sekaligus rancangan pembangunan hukum nasional. Hasil dari pencapaian dari proses pembangunan ini dapat membantu terwujudnya tujuan hukum yang mengarah pada tujuan suatu negara. Dengan demikian perlu diperhatikan bahwa terwujudnya tujuan hukum secara otomatis mengarah pada rencana dari tujuan suatu negar itu sendiri.

Secara praktis pembangunan dapat diterjemahkan sebagai upaya untuk memperbaharui sesuatu yang buruk ke arah yang lebih baik. Sehinggal makna dari kata pembangunan identik dengan kata reform (pembaharuan), hal tersebut memiliki makna bahwa adanya ketergantungan terhadap suatu kebijakan dalam melakukan reorientasi dan reformasi ke arah positif. Sondang P. Siagian berpendapat bahwa kebijakan yang moderat sangat diperlukan dalam melakukan proses pembangunan dan pembaharuan dalam rangka menuju ke arah modernisasi. Karena rangkaian dalam sebuah pembangunan bertujuan untuk memperbaiki kekurangan dari berbagai aspek kehidupan masyarakat, terkhusus dari segi hukum yang berperan menjadi sebuah aturan dalam menjalankan aspek-aspek yang lainnya.

Pembangunan dari segi hukum mempunyai dua arti, diantaranya; Pertama, untuk memperbaharui hukum yang ada, salah satunya, yaitu memperbaharui hukum positif ke arah modernisasi hukum sebagai upaya untuk mengimbangi perkembangan zaman yang sangat pesat. Kedua, hukum dapat menjadi alat fungsional, dalam artian hukum secara beriringan turut mengadakan perubahan sosial dengan masyarakat yang berupaya ikut andil dalam proses pembaharuan hukum. Pembaharuan hukum tidak terbatas hanya pada kegiatan-kegiatan legislasi, melainkan terhadap upaya untuk menjadikan hukum sebagai alat rekayasa sosial (social engineering). Oleh sebab itu, pembangunan hukum dapat diterjemahkan suatu cara di dalam proses amandemen suatu hukum guna memperbaharui hukum yang lama yang sudah tidak relevan dengan kondisi masyarakat (Atmaja, 2014).

Dalam proses pembangunannya hukum berperan dalam menjamin agar perubahan yang dicitacitakan terwujud dengan cara yang sudah di rencanakan. Peran aturan perundang-undangan serta kebijakan dari pemerintahan sangat berpengaruh pada proses pembangunan terutama dalam mewujudkan hukum yang ideal. Dalam proses pembangunan hukum harmonisasi hukum sangatlah dibutuhkan. Kebijakan yang dianggap baik serta keputusan pengadilan yang adil di dukung dengan masyarakat dengan budaya yang baik dapat membatu mempercepat proses terbentuknya hukum yang lebih baik (Kansil, 1992). 
Hukum yang baik diawali dengan proses yang baik pula, karena melaui kekerasan serta paksaan hanya akan menimbulkan efek buruk untuk generasi yang akan datang. Karena hukum yang dibentuk sekarang akan dipakai oleh generasi penerus yang akan meneruskan perjuangan yang sedang dilakukan.

Dalam hal ini, Indonesia melalui pembukaan UUD 1945 alenia ke empat menjelaskan mengai tujuan ideal dibentuknya suatu negara (Staatfundamentanorm), yaitu: pertama, melindungi segenap bangsa Indonesia dan seluruh tumpah darah Indonesia; kedua, memajukan kesejahteraan umum; ketiga, mencerdaskan kehidupan bangsa; keempat, ikut serta melaksanakan ketertiban dunia berdsarkan kemerdekaan, perdamaian abadi dan keadilan sosial.

Politik hukum menjadi pengaruh besar dalam menjalankan proses pemerintahan ataupun dalam proses pembentukan suatu kebijakan. Karena didalamnya terdapat unsur-unsur politis serta ide-ide individu ataupun kelompok yang dituangkan di dalamnya. Dalam mengatur masyarakat hal tesebut sangat berpengaruh karena produk dari kebijakan merupakan hasil dari proses politik hukum yang dilakukan. Baik tidaknya kebijakan tergantung politik hukumnya. Dalam hal ini Mahfud MD menjelaskan bahwa dalam sistem hukum di Indonesia terdapat kesatuan dan pengaturan perundang-undangan yang terdiri dari berbagai komponen yang saling ketergantungan satu sama lainnya, yang dibangun untuk mencapai tujuan negara dengan berpedoman pada dasar dan cita hukum nasional yang terkandung di dalam Undang-Undang Dasar 1945 (Moh. Mahfud MD, 2012).

Mengenai hal tersebut maka tujuan negara antara relevansi politik hukum dalam satu sistem hukum nasional, setidaknya mencakup beberapa aspek, yaitu: pertama, mengenai tujuan masyarakat atau negara indonesia, yaitu sebagai orientasi politik hukum, termasuk seruan dalam nilai-nilai dasar serta tujuan negara sebagai pemandu politik hukum; kedua, sistem hukum nasional yang dibutuhkan dalam mencagai tujuan tersebut serta faktor-faktor yang mempengaruhinya; ketiga, Kerangka pikir dan Perencanaan dalam perumusan suatu kebijakan hukum; keempat, Isi hukum nasional serta faktor-faktor yang dapat mempengaruhinya; kelima, Prolegnas dengan pemagaran hukum serta judicial review, legislative review, dan sebagainya (Alamsyah \& Huda, 2013).

\section{Politik Hukum dalam Menghadapi Dampak Revolusi Industri 4.0}

Indonesia merupakan negara hukum dengan memiliki banyak budaya serta adat istiadat yang dianut oleh masyarakatnya. Terlebih lagi payung hukum yang dipegang bangsa ini terdiri dari hukum posistif, hukum islam, dan hukum adat. Harmonisasi diantara ketiganya sangatlah dibutuhkan dalam proses kemjuan serta pembaharuan hukum yang ada di Indonesia. Dalam pembentukannya pemerintah harus bisa memperhatikan budaya hukum yang ada dalam masyarakat serta cara pandang masyarakat terhadap hukum tersebut.

Melihat hal tersebut diiringi dengan munculnya tren Revolusi Industri 4.0 dan dengan berbagai dampak yang ditimbulkan, secara beriringan muncul persoalan-persoalan baru dan dengan kompleksnya persoalan baru tersebut. Sehingga ada beberapa persoalan yang tidak bisa terselesaikan dengan tuntas, dengan alasan belum ada aturan yang mengatur persoalan tersebut di dalam undang-undang, yang kemudian menimbulkan efek kesenjangan di dalam kehidupan bermasyarakat.

Pemerintah dengan kebijakannya mengeluarkan undang-undang yang dikenal dengan undangundang ITE yang bertujuan untuk menghadapi persoalan persoalan yang muncul didalam masyarakat. Undang-undang tersebut dibentuk melalui kesepakatan bersama dalam rapat paripurna antara pemerintah dengan DPR. Hasil dari kesepakatan tersebut mengandung amanat penting bagi masyarakat agar membangun etika dalam penggunaan media sosial sehingga lebih berhati-hati dan bijak dalam menggunakan media sosial (Rajab, 2018). 
Uapaya yang dialakukan pemerintah merupakan sikap dan respon dalam melihat gentingnya fenomena yang terjadi, yaitu semakin maraknya pelanggaran-pelanggaran serta tindakan yang diluar batas yang tidak sesuai dengan budaya yang dimiliki bangsa ini. Indonesia dikenal dengan masyarakatnya yang ramah serta budayanya yang beragam. Mencermin dari hal itu maka sepatutnya kelestarian baik itu etika maupun budaya harus tetap dijaga dengan kuat sehingga akan terjaga dengan baik.

Bangsa yang beradab merupakan bangsa yang dicita-citakan dengan memiliki aturan hukum yang adil dan tegas dalam penindakannya. Masyarakat yang segan akan hukum serta taat akan aturan yang ada di dalamnya merupakan isapan jempol belaka jika tanpa didasari dengan budaya yang baik serta hukum yang baik pula. Hukum yang terbentuk dari proses politik hukum menjadi awal dari terbentuknya ketertiban hukum, karena produk yang dihasilkan akan berpengaruh terhadap berbagai tatanan yang ada dalam masyarakat.

Pembaharuan hukum perlu dilakukan dalam rangka mengimbangi proses perubahan zaman. Karena hukum harus bisa mengatur dan menyelesaikan prosoalan-persoalan yang timbul dari fenomena yang ada. indonesia adalah negara hukum sepantasnya lebih memperhatikan produk hukum yang dihasilkannya apakah hukum tersebut berkualitas tidaknya serta bisa menertibkan masyarakat atau tidaknya. Dalam undang-undang ITE diatur mengenai bagaimana cara bertindak dalam bersosial yang baik. Dalam undang-undang ini membatasi masyarakat dalam memberikan informasi yang dianggap merugikan orang lain dan mengarah kepada tindak pidana. Dalam pengaturannya peran mengenai Hak Asasi Manusia harus benar-benar diperhatikan karena asas keadilan dan asas persamaan atas hukum sangat lah berkaitan di dalamnya.

Udang-udang ITE yang baru dikeluarkan oleh pemerintah yaitu Undang-Undang Nomor 19 Tahun 2016 yang disahkan pada oktober 2016 lalu menjadi tombak dalam penanganan tidak kejahatan yang ada dalam media sosial, hal tersebut merupakan salah satu pembaharuan hukum yang dianggap perlu untuk menyelesaikan persoalan-persoalan yang belum terselesaikan dengan baik.

Dalam undang-undang tersebut terdapat perubahan dalam beberapa Pasal, yaitu Pasal 27 ayat (1) dan (3), Pasal 28 ayat (2), dan Pasal 31 ayat (3). Yang isinya membahas mengenai : perbaikan kata yang multitafsir agar tidak ada kesalah pahaman dalam mengartikannya; menjelaskan mengenai penurunan acaman hukuman pidana; melaksanakan putusan dari Mahkamah Konstitusi; melakukan sinkronisasi dalam ketentuan hukum yang ada dalam KUHP; adanya penghapusan ketentuan yang dianggap menjadi pelanggaran dengan pengapusan informasi/ hak untuk dilupakan; serta memperkuat peranan pemerintah dan kewenangannya dalam memberikan perlindungan dalam penyalahgunaan informasi dan transasksi elektronik.

Adanya perubahan tersebut merupakan tindakan dalam proses penanganan persoalan yang menjadi polemik dalam masyarakat. Akan tetapi ada juga berbagai kalangan yang mengkritik prihal perubahan undang-undang tersebut diantaranya yaitu mengenai penambahan peranan serta kewenangan pemerintah. Dalam hal ini seolah ada anggapan bahwa pemerintah tidak mau dikritik oleh masyarakat sehingga adanya defance dari pemerintah dengan memunculkan revisi undang-undang ITE tersebut. Hal ini memicu polemik masyarakat dalam hak kebebasan berpendapat.

Dengan adanya penambahan kewenangan serta peran pemerintah yang dianggap terlalu memonopoli menyebabkan masyarakat seakan bungkan terhadap rasa ketidak adilan serta kritis masayarakat terhadap pemerintah yang melakukan pelanggaran. 


\section{SIMPULAN}

Dari pemaparan tersebut ditariklah kesimpulan bahwa politik hukum mempunyai peran sangat penting di dalam proses pembaharuan hukum guna mengimbangi pesatnya perkembangan zaman. Pembaharuan hukum merupakan cerminan dalam upaya mewujudkan amanat dari pembukaan UUD 1945 alenia ke empat serta ketentuan-ketentuan lain yang ada di dalamnya. Dalam menghadapi zaman modern serta adanya tren revolusi industri 4.0 ini hukum dituntun untuk bisa menjadi pedoman dalam mengatur masyarakat serta bisa menjadi soslusi dari permasalahan-permasalahan kompleks yang muncul dalam kehidupan bermasyarakat. hukum yang ditegakkan harus sesuai dengan ketentuan yang ada dengan tidak membeda-bedakan kalangan masyarakat hal tersebut sebagai cerminan dalam menjalankan amanat dari UUD 1945 yang mengatakan bahwa indonesia merupakan negara hukum dengan asas keadilan, asas persamaan serta asas kepastian hukumnya. Adanya revisi dari undang-undang ITE ini adalah produk dari politik hukum yang diharapkan menjadi solusi dalam menghadapi persoalanpersoalan yang muncul beriringan dengan semakin pesatnya laju pertumbuhan yang ada di dalam masyarakat.

\section{DAFTAR PUSTAKA}

Alamsyah, B., \& Huda, U. N. (2013). POLITIK HUKUM PELEMBAGAAN KOMISI-KOMISI NEGARA DALAM SISTEM KETATANEGARAAN INDONESIA. Jurnal Hukum Dan Peradilan, 2(1), 85108.

Astuti, S. A. (2019). Impact of Industrial Revolution 4.0 and the Utilization of Digital Media Technology towards Siber Community Behavior [Dampak Revolusi Industri 4.0 Dan Kemanfaatan Teknologi Media Digital Terhadap Perilaku Buruk Masyarakat Siber]. Proceeding of Community Development, 2, 483-494.

Atmaja. (2014). Kedaulatan Negara Di Ruang Maya: Kritik UU ITE Dalam Pemikiran Satipto Rahardjo. Jurnal Opinio Juris, 15(1).

Idayanti, S., Hartati, S., \& Haryadi, T. (2019). Pembangunan Hukum Bisnis Dalam Perspektif Pancasila Pada Era Revolusi Industri 4.0. Jurnal Jurisprudence, 9(1), 90-101.

Kansil, C. S. T. (1992). Pengantar ilmu hukum dan tata hukum Indonesia. Balai Pustaka.

Moh. Mahfud MD. (2012). Membangun Politik Hukum Menegakkan Konstitusi. Jakarta. Jakarta: Rajawali Press.

Mukhadis, A. (2013). Sosok manusia indonesia unggul dan berkarakter dalam bidang teknologi sebagai tuntutan hidup di era globalisasi. Urnal Pendidikan Karakter, 2(2).

Palinggi, S., \& Allolinggi, L. R. (2019). Analisa Deskriptif Industri Fintech di Indonesia: Regulasi dan Keamanan Jaringan dalam Perspektif Teknologi Digital. Ekonomi Dan Bisnis UPNVJ, 6(2), 177-192.

Palinggi, S., Palelleng, S., \& Allolinggi, L. R. (2020). Peningkatan Rasio Kejahatan Cyber Dengan Pola Interaksi Sosio Engineering Pada Periode Akhir Era Society 4.0 di Indonesia. Jurnal Ilmiah Dinamika Sosial, 4(1), 145-163.

Rahardjo, S. (2006). Hukum dalam Jagat Ketertiban (Bacaan Mahasiswa Program Doktor Ilmu Hukum Universitas Diponegoro). Uki Press.

Raharjo, A. (2002). Cybercrime: Pemahaman dan upaya pencegahan kejahatan berteknologi. Citra Aditya Bakti.

Rajab, A. (2018). Urgensi Undang-Undang Nomor 19 Tahun 2016 Tentang Perubahan Atas UndangUndang Nomor 11 Tahun 2008 Tentang Informasi Dan Transaksi Elektronik Sebagai Solusi Guna Membangun Etika Bagi Pengguna Media. Jurnal Legislasi Indonesia, 14(4), 463-471.

Saebani, B. A. (2016). Perspektif Perubahan Sosial. Bandung: CV Pustaka Setia.

Soekanto, S. (1980). Pokok-pokok sosiologi hukum. Rajawali. 


\section{Khazanah Hukum, Vol. 2 No. 2: 65-72}

Penerapan Undang-Undang ITE ; untuk Menghadapi Dampak Revolusi Industri 4.0 Alwi Al Hadad

Sujamawardi, L. H. (2018). Analisis Yuridis Pasal 27 ayat (1) Undang-Undang Nomor 19 Tahun 2016 tentang Perubahan atas Undang-Undang Nomor 11 Tahun 2008 tentang Informasi dan Transaksi Elektronik. Dialogia Iuridica: Jurnal Hukum Bisnis Dan Investasi, 9(2). 